\title{
Development of Teaching Materials Introduction to Statistics Using E-learning for Students of Jakarta State University
}

\section{Yuliatri Sastra Wijaya, Erdawati Kamaruddin, and Muhammad Ficky Duskarnaen}

Pendidikan Informatika, Fakultas Teknik Universitas Negeri Jakarta

\section{Abstract}

The results of this study of introductory statistics teaching materials for students of Jakarta State University in the form of e-learning can be used online, making it easier for students and lecturers to develop, apply, discuss, and assess the teaching material to teach. This research was carried out with G\&D's R\&D research model, which consisted of 10 steps, from planning to testing the effectiveness of the program. This study consists of three stages, which is now being run on the second stage. In this second phase, a trial was conducted for 80 Informatics Education students, with an

Corresponding Author: Yuliatri Sastra Wijaya yuliatri@unj.ac.id

Received: 11 January 2019 Accepted: 14 February 2019 Published: 25 March 2019

Publishing services provided by Knowledge E

(c) Yuliatri Sastra Wijaya et al. This article is distributed under the terms of the Creative Commons Attribution License, which permits unrestricted use and redistribution provided that the original author and source are credited.

Selection and Peer-review under the responsibility of the 3rd ICTVET 2018 Conference Committee.

\section{G OPEN ACCESS}

\section{Introduction}

Education an infrastructure for the development of human resources in achieving a better quality of life and in facing the global challenges that developing at this time, so that to get quality human resources the implementation of education must be able to maximally improve the ability of students, through directed education processes and dynamics. The existence of educational institutions must be balanced with an increase in the quality of education, it will a primary responsibility of an educational institution in entering the era of globalization, and digital communication to prepare qualified students to face various challenges that exist in society after they finish their studies.

Jakarta State University (UNJ) as one of the educational institutions high has the role and function of preparing reliable and competitive human resources according 
to their fields which the assets of the Indonesian people, government and nation so that they can contribute to the development of the nation and the State of Indonesia. Various programs that have developed according to UNJ's vision to become universities that have competitive advantages in building an advanced, democratic and prosperous society based on Pancasila in the era of globalization. The pioneering towards this has done by fixing various academic aspects that at the heart of educational activities at UNJ.

E-learning a concept of learning based on technology both information technology, telecommunications, and digital. E-learning can interpret as a learning medium that does not use paper as its material. E-learning can used as a paradigm for modern education. One of the advantages of e-learning itself revealed by Pei-Chen Sun The significant advantage of e-learning includes liberating interactions between learners and instructors, from the limitation of time and space through the asynchronous learning network model [1].

This in line with the UNJ Research Master Plan based on the research theme in the field of Educational Technology based on selected topics on teaching materials developed through ICT media. The teaching material that will develop the Educational Statistics Course as a compulsory subject in the group UNJ. The application of research in various educational technology-based disciplines aims to implement learning model innovations and learning media in the subjects to develop. This research will answer the following problems, How to add power points to the materials of Statistics teaching materials based on e-learning to improve the quality of learning planning, and how to implement e- learning statistics for the learning process to create a fun and innovative learning process.

This in line with the research conducted by Muhammad Munir in Yogyakarta [2] on Multi Media-based E-learning that can improve the quality of learning of vocational students. Research on the effectiveness of E-learning as a Learning Media by Nurniek Sulistyo Hanum [3] states that e- learning effectively improves student learning outcomes in FT when viewed from the aspect of e- learning planning quite useful category. Likewise, Hasbullah's research [4] with the title Development of the E-learning Learning Model a rapid increase in learning in energy and conversion courses.

\section{Methods and Equipment}




\subsection{Methods}

This research carried out using a research and development model (R \& D) from Borg and Gall [5] which included 10 steps in 3 stages of activities, namely

\section{First Stage (First Year)}

\subsection{Research and data collection (Research and information collecting)}

This step carried out to collect various information related to the implementation process of making e-learning at FT UNJ. This effort carried out through a literature review related to the theory and concept of e-learning, as well as through field assessments to see the pattern of implementation-learning that will held on campus. Also, studies also conducted on various problems or obstacles that might encountered in implementing e-learning.

\subsection{Planning (Planning)}

This activity carried out concerning the results of the preliminary study (the first phase) which followed by a more in-depth study of the pattern of integration of lecturers' activities in implementing e-learning. E-learning that will used as a reference by programmers in developing the program. In order for the development process to more efficient, the first generated storyboard will be discussed in depth with various competent parties, including with some Statistics and program experts. From the results of the discussion, the storyboard will revised according to the input, and the results will be submitted to the programmer to develop the draft program.

\subsection{Development of product draft (Develop a preliminary form of product)}

The product that will produced in this research-learning statistics that will be used by FT lecturers in carrying out the learning process. E-learning will be developed based on Moodle. At this stage, a review also carried out by the researcher, and the results discussed with the programmer. This process is done to avoid mistakes from the start. The final result of this stage a prototype e-learning application program that will use by lecturers in designing and developing teaching materials. 


\subsection{Expert review (Expert review)}

At this stage, e-learning will be reviewed by experts to see weaknesses and errors that occur in e-learning. The review carried out by Statistics experts (subject matter experts), information and communication technology experts, educational technology practitioners.

\subsection{System review based on expert reviews}

By referring to the input submitted by experts and practitioners, the system will improved to get a better system seen from the academic side.

The essence of the first year research to do a formative evaluation. Formative evaluation is done to get input from experts and practitioners related to the weaknesses and shortcomings of the system to immediately repaired/revised.

\section{The Second Stage (Second Year)}

\subsection{Preliminary field testing}

At this stage, the e-learning application program prototype generated from step 3 will tested on a limited scope.

\subsection{Revise test results (Main product revision)}

Based on the results of the initial phase of the trial, it will revised on aspects of the application program which considered to still not support the optimization of the implementation of e- learning as a whole. Through this phase, e-learning programs expected to obtain, because improvements have made to weaknesses in each aspect of the program.

\subsection{Field test (Central field testing)}

At this stage the e-learning program will be used by lecturers in planning and implementing learning. At this stage the number of participants was more than in the initial field trials. 


\subsection{Enhancing the product of operational product revision}

At this stage, product enhancements will be made based on expert evaluation results.

\section{Third Year}

\subsection{Dissemination and implementation}

\section{Results}

\subsection{Results of Moodle-based statistics learning products}

The results of this study Statistics teaching materials for UNJ students based on Moodle e- Learning (Modular Object-Oriented Dynamic Learning Environment), which contain teaching materials, PowerPoint display of teaching materials, which have validated by material experts and instructional media experts and in conformity testing to students Moodle here functions as a Learning Management System (LMS). Moodle can be used freely as an open source product under the General Public License (GPL) license. The systematic design of Moodle-based e-Learning as follows: Get webhosting, set e-Learning Identity, change themes, and create users.

Understanding Introduction to Statistics. Introduction Statistics a compulsory subject for UNJ students. This course given in semester 4 or 5 . Learning emphasizes the introduction of the meaning of Statistics and other supporting tools in the Introduction to Statistics. The e-learning material for Introduction to Statistics has tested for as many as 80 students, with an average of 83.5, and students have also filled out questionnaires as much as $83 \%$ said using e-learning fun and can repeated material that has not mastered and can discuss with friends online. The improvement of the Lecturers a revision of some teaching materials about typos and interpretation.

Display Statistics material based on Moodle 

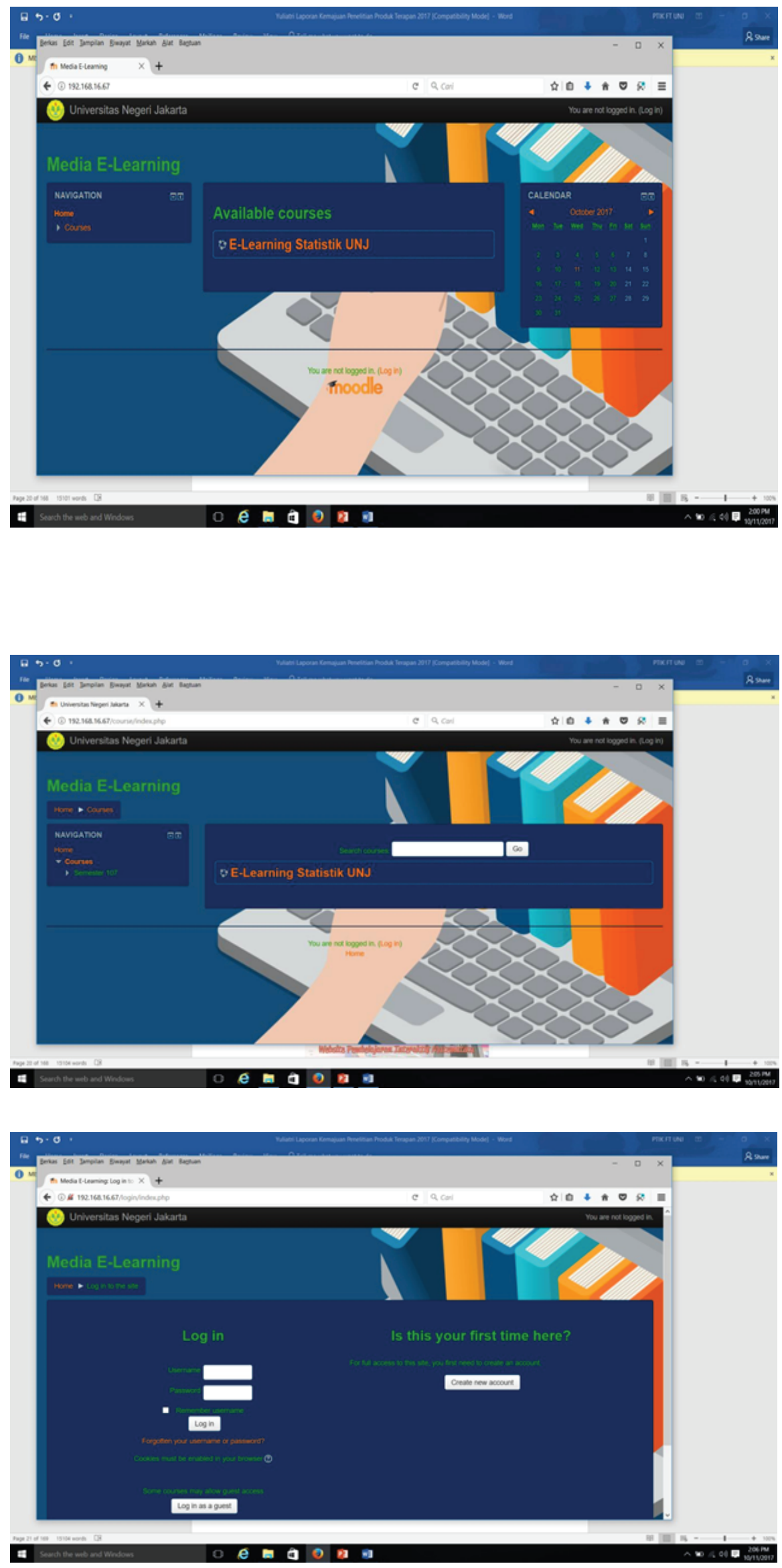

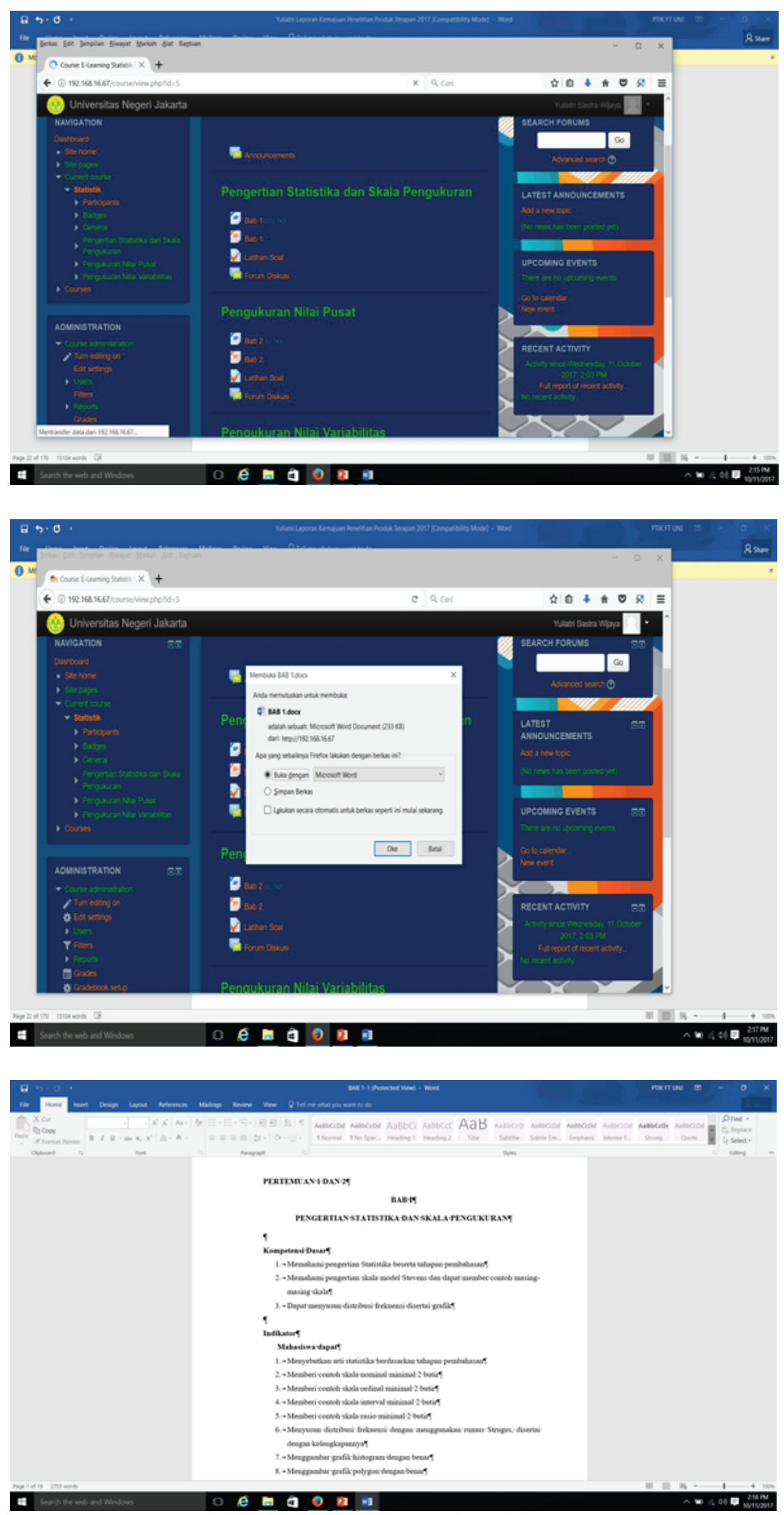


\section{Discussion}

Through the e-learning application with Moodle, the task of the lecturers to manage lecture material to prepare a syllabus, upload (lecture) lecture material, assign assignments to students, accept, student/student work, make tests/quizzes, provide grades, monitor student activity, process value of students/students, interacting with students and fellow lecturers through discussion and chat forums, and so on. On the other hand, students can access information and learning materials interacting with students and fellow lecturers, transact lecture tasks, do tests/quizzes, see the achievement of learning outcomes, and so on. One of the advantages for lecturers who make onlinebased learning models based on Moodle convenience. Lecturers do not need to know a bit about the web programming language so that the time available can use more to think about the content (content) of the learning to delivered.

The benefit of this research to produce e-learning application program for Statistics courses that can be used by UNJ lecturers and students in lectures, discussions, and more detailed studies of matters relating to Statistics both to solve these problems or others. The e-learning application equipped with discussion features with lecturers and peers.

As for some of the uses and benefits of this study include: College student:

- Students can take advantage of e-learning, as a source of learning, so that in learning students not bound by time and day and do not depend on the presence of the teacher.

- Statistics e-learning products can help students understand the difficulties of learning statistics.

- Providing forms of learning services in presenting exciting material for students to learn about the topics of Statistics which considered difficult.

\section{For Lecturers}

- Helping in delivering teaching material in achieving Statistics learning goals

- Moodle-based e-learning products can used as learning materials and resources.

\section{Conclusion}

Based on the analysis of several stages of research that have carried out, it can concluded as follows. 
1. Statistics is learning material even though only introductory turned out to quite tricky for Engineering group students because they came from Vocational Schools as well as those from high school.

2. To overcome these difficulties an e-learning learning model created so that they could look back at what the lecturer had explained.

3. E-learning produced by the new initial stage the appearance of material, PowerPoint, and a little discussion.

\section{Suggestion}

In order to contribute ideas regarding e-learning learning at UNJ, the following recommended.

1. It better for researchers to develop teaching materials equipped with films or videos relating to the material displayed.

2. Lecturers should give guidance on 1 or 2 meetings in using e-learning.

\section{References}

[1] Pei-Chen Sun, Computer and Education 50, 2008

[2] Muhammad Munir, staffnew.uny.ac.id/upload/131808684/penelitian/jurnal+ +penelitian+FT-2011.pdf

[3] Nurniek Sulistyo Hanum (Journal of Educational Vocational, 2014) https://journal. uny.ac.id/index.php/jpv/article/view/1584

[4] Hasbullah's (Journal of Educational Research, 2015) jurnal.upi.edu/file/Hasbullah.pdf

[5] Clark, Ruth C. and Mayer, Richard E. 2003. E-learning and the Science of Instruction. San Francisco: Pfeiffer. 